\title{
Analisis Implementasi Pembuatan Akta Tanah/Sertipikat Tanah di Badan Pertanahan Nasional Republik Indonesia Melalui Kelompok Masyarakat (POKMAS) Kantor Pertanahan Kabupaten Lampung Barat (Studi di Desa Kuta Besi Kecamatan Batu Brak Kabupaten Lampung Barat)
}

\author{
Lintje Anna Marpaung ${ }^{1}$, Anggalana², Eky Sepriza ${ }^{3}$ \\ ${ }^{1,2,3}$ Fakultas Hukum Universitas Bandar Lampung \\ Jln. ZA. Pagar Alam No. 26 Labuhan Ratu Bandar Lampung Provinsi Lampung \\ Correspondence email: Eky.Sepriza.17211033@student.ubl.ac.id
}

\begin{abstract}
Abstrak. Sertipikat Tanah merupakan hal yang penting dalam Negara Hukum dikerenakan sebagai bukti kepemilikan yang terkuat yang dimiliki oleh seseorang jika status tanahnya ingin diakui oleh Hukum, tanpa adanya sertifikat dapat dipastikan orang yang mengaku atas tanah tersebut dapat dibatalkan kepemilikan tanahnya. selain itu sertipikat tanah juga dapat dijual atau dialihkan kepada orang lain atau diwariskan kepada anak-anaknya, dalam Pembuatan Akta Tanah/Sertipikat di Desa Kuta Besi Kecamatan Batu Brak Kabupaten Lampung Barat saat ini banyak masyarakat belum memiliki sertifikat tanah resmi dari BPN, oleh sebab itu masyarakat yang sadar akan hukum mendirikan organisasi Pokmas yang berkerjasama langsung dengan BPN Lampung Barat sebagai upaya untuk membantu masyarakat dalam pembuatan sertipikat tanah yang lebih effisien dan efektif, dan juga tujuan didirikan organisasi pokmas untuk memberikan sosialisasi langsung kepada masyarakat mengenai hak masyarakat atas kepemilikan tanah, metode penelitian ini menggunakan pendekatan yang bersifat yuridis normatif dengan menggunakan perundang-undangan yang terkait dengan Pendaftaran Tanah dan Pendekatan empiris yaitu dilakukan dengan melihat secara langsug terkait objek penelitian dengan cara observasi dan wawancara.
\end{abstract}

Kata kunci: Pendaftaran tanah; Pokmas; Implementasi

\begin{abstract}
A land certificate is important in a rule of law because it is the strongest proof of ownership owned by a person if the status of the land is to be recognized by the law, without a certificate it can be ascertained that the person who claims the land can be canceled. In addition, land certificates can also be sold or transferred to other people or inherited to their children. In the Making of Land Deeds / Certificates in Kuta Besi Village, Batu Brak District, West Lampung Regency, currently many people do not have official land certificates from BPN, therefore People who are aware of the law establish a Pokmas organization that collaborates directly with the West Lampung BPN as an effort to assist the community in making land certificates that are more efficient and effective, and also the purpose of establishing a community group organization is to provide direct socialization to the community regarding community rights to land ownership, methods This research uses a normative juridical approach using legislation related to Land Registration and an empirical approach, which is carried out by looking directly at the object of research by means of observation and interviews.
\end{abstract}

Keywords: Land registration; Pokmasp; Implementation

\section{PENDAHULUAN}

Indonesia ialah Negara hukum hal ini sesuai dengan ketentuan yang ada dalam Pasal 1 ayat (3) jo Pasal 27 ayat (1) jo Pasal 28D ayat (1) Undang-Undang Dasar Negara Republik Indonesia 1945 yang menyatakan bahwa dalam Pasal 1 ayat (3)," Negara Indonesia adalah Negara Hukum, dan selanjutnya dalam Pasal 27 ayat (1)," Segala warga negara bersamaan kedudukannya di dalam hukum dan pemerintahan dan wajib menjunjung hukum dan pemerintahan itu dengan tidak ada kecualinya". Wajib ikut serta dalam upaya pembelaan Negara, dan Pasal 28D ayat (1), "Setiap orang berhak atas pengakuan, jaminan, perlindungan, dan kepastian hukum yang adil serta perlakuan yang sama di hadapan hukum.

Konsekuensi dalam negara hukum mendapatkan kepastian hukum terhadap suatu objek sangatlah penting karena dapat menghindari bilamana terjadi nya sengketa di kemudian hari, begitu juga hal nya dengan hak kepemilikan atas tanah. Di Indonesia Tanah mempunyai makna dan posisi yang sangat strategis dalam kehidupan di masyarakat Indonesia yang memiliki sifat agraris. karena sedemikian istimewanya arti tanah dalam kehidupan masyarakat Indonesia ini bisa telihat dan tercermin dalam sikap bangsa Indonesia atas tanah yang memberikan penghormatan kepada kata tanah. Tanah air, Tanah tumpah darah, Tanah pusaka dan sebagainya, menyadari betapa pentingnya nilai yang terkandung di dalam arti kata tanah tersebut. Pemerintah dengan segera merumuskan arti makna tentang tanah dan sumber daya alam secara ringkas tetapi sangat filosofis dan substansial, ${ }^{1}$

${ }^{1}$ Steven Octovia Kennedy Wowor. 2016. Responsivitas Dalam Pendaftaran Peralihan Hak Atas, Tanah Jual Beli Di Kantor Pertanahan Dikabupaten Sigi Provinsi Sulawesi Tengah. E Jurnal Katalogis, Volume 4 Nomor 1, hlm. 147. 
Lintje Anna Marpaung, Anggalana dan Eky Sepriza, Analisis Implementasi Pembuatan Akta Tanah/Sertipikat Tanah di Badan Pertanahan Nasional Republik Indonesia Melalui Kelompok Masyarakat (POKMAS) Kantor Pertanahan Kabupaten Lampung Barat (Studi di Desa Kuta Besi Kecamatan Batu Brak Kabupaten Lampung Barat)

Menurut kamus besar bahasa Indonesia tanah ialah : permukaan bumi yang terbatas yang ditempati suatu bangsa yang diperintah suatu negara atau menjadi daerah Negara. ${ }^{2}$ sedangkan menurut E. Saifudin Sarief : tanah adalah benda alami yang terdapat di permukaan bumi yang tersusun dari bahan-bahan mineral sebagai hasil pelapukan batuan dan bahan organik "pelapukan sisa tumbuhan dan hewan" yang merupakan medium pertumbuhan tanaan dengan sifat-sifat tertentu yang terjadi akibat gabungan dari faktor-faktor alami, iklim, bahan induk, jasad hidup, bentuk wilayah dan lamanya waktu pembentukan. ${ }^{3}$

Pasal 33 ayat (3) Undang-Undang Dasar Negara Republik Indonesia 1945 yang menyatakan bahwa: "Bumi dan air dan kekayaan alam yang terkandung di dalamnya dikuasai oleh negara dan dipergunakan untuk sebesar-besarnya kemakmuran rakyat, bunyi apa yang dimaksud oleh ketentuan pasal 33 ayat (3) tersebut memiliki makna yaitu:

1. Bahwa bumi, air dan kekayaan alam yang terkandung di dalam nya dikelola untuk mencapai kemakmuran rakyat

2. Pengelolaan bumi, air dan kekayaan alam yang terkandung di dalam nya di kelola oleh Negara

3. Tujuan dari pengelolaan bumi,air dan kekayaan alam yang terkandung di dalam nya sebesar-besarnya untuk kemakmuran rakyat.

Undang-Undang Dasar Negara Republik Indonesia 1945 merupakan dasar hukum dalam pembentukan hukum agraria Nasional serta sebagai dasar hukum pertama dalam pembentukan mengenai peraturan perundang-undangan yang mengatur persoalan bumi, air dan kekayaan alam yang terkandung di dalamnya.

Manusia dan tanah memiliki kedekatan yang erat seperti halnya melakukan aktivitas pekerjaan dan kegiatan sehari-hari dan juga manusia mendirikan rumah di atas tanah untuk digunakan sebagai tempat tinggal atau bekerja, kebutuhan tanahpun sangat meningkat tajam dengan banyak nya penduduk Indonesia sekarang ini sehingga membutuhkan tanah/lahan untuk membangun tempat tinggal. Pasal 1 angka 1 Peraturan Pemerintah Nomor 24 Tahun 1997 tentang Pendaftaran Tanah adalah : serangkaian kegiatan Yang dilakukan oleh pemerintah secara terus menerus, berkesinambungan dan teratur meliputi pengumpulan, pengolahan, pembukuan, dan penyajian serta pemeliharaan data fisik dan data yuridis, dalam bentuk peta dan daftar, Mengenai bidang-bidang tanah dan satuan-satuan rumah susun, termasuk pemberian surat tanda bukti haknya bagi bidang-bidang tanah yang sudah ada haknya dan hak milik atas satuan rumah susun serta hak-hak tertentu yang membebaninya. pendaftaran tanah dilakukan dalam bentuk peta dan daftar demikian pula dapat kita ketahui bahwa salah satu rangkaian kegiatan pendaftaran tanah adalah pemeliharaan data fisik dan data yuridis yang juga dilakukan dalam bentuk peta dan daftar yang memuat data fisik dan data Yuridis dari bidang-bidang tanah dan satuan rumah susun. ${ }^{4}$

Pendaftaran tanah, sebagai pelaksanaan Pasal 19 Undang-Undang Nomor 5 tahun 1960 tentang Pokok Agraria (selanjutnya di singkat UUPA) merupakan salah satu upaya Pemerintah untuk memberikan jaminan kepastian hukum yang meliputi, jaminan kepastian hukum mengenai individu dan badan hukum yang menjadi pemilik yang berhahak terhadap hak atas tanah tersebut dan jaminan kepastian Hukum mengenai letak, batas, dan luas suatu bidang tanah serta jaminan kepastian hukum mengenai hak-hak atas tanahnya. ${ }^{5}$

Pendaftaran tanah merupakan salah satu rangkaian kegiatan yang dilaksanakan oleh pemerintah yang dilakukan secara terus-menerus, berkesinambungan dan teratur, melalui pengumpulan data, pengolahan data, pembukuan, dan penyajian serta pemeliharaan yang meliputi data fisik dan data Yuridis, dalam bentuk peta dan daftar mengenai bidang-bidang tanah dan satuan-satuan rumah susun termasuk pemberian sertifikat dan juga sebagai tanda bukti sahnya kepemilikan hal ini di pertegas sesuai yang tertuang dalam Pasal 19 ayat (1) Undang-Undang Nomor 5 tahun 1960 tentang Pokok Agraria yaitu ," Untuk menjamin kepastian hukum oleh Pemerintah diadakan pendaftaran tanah di seluruh wilayah Republik Indonesia menurut ketentuan-ketentuan yang diatur dengan Peraturan Pemerintah.

Hak tersebut berarti bahwa selama belum dibuktikan sebaliknya maka data fisik dan data yuridis yang dalam sertipikat harus diterima sebagai data yang benar oleh karena itu sertipikat merupakan suatu tanda bukti kepemilikan yang sah dan jaminan kepastian hukum serta perlindungan oleh hukum dari Pemerintah kepada rakyat dalam mempertahankan kepemilikanya atas tanah yang mereka miliki. Jaminan kepastian hukum meliputi bagi bidangbidang tanah yang sudah ada akta nya dan hak milik atas Satuan Rumah Susun hak-hak membebaninya. ${ }^{6}$

Data yuridis sebagaimana dimaksud dalam Pasal 1 angka 6 Peraturan Pemerintah Nomor 24 Tahun 1997 mengenai status hukum dalam sebidang tanah yang didaftarkan oleh pemegang atas tanah dan hak pihak lain serta beban-beban lain yang membebaninya, dalam kasus ini tepat nya di Desa Kuta Besi Kec/Batu Brak Kab.Lampung

\footnotetext{
${ }^{2}$ Kamus Besar Bahasa Indonesia, Diakses 22 Oktober 2020

${ }^{3}$ https://www.seputarpengetahuan.co.id.Pengertian-Tanah-Menurut-Para-Ahli.html. Diakses Pada Tanggal 22/10/2020 Jam

${ }^{4}$ Arba. 2017. Hukum Agrarian Indonesia. Sinar Grafika, Jakarta, hlm.148.

${ }^{5}$ A. P. Parlindungan. 1993. Komentar Undang-Undang Pokok Agraria. Mandar Maju, Bandung, hlm. 15.

${ }^{6}$ Arie Sukanti Hutagalung. 2012. Pentingnya Pendaftaran Tanah di Indonesia. Raih Asa Sukses, Jakarta, hlm.8.
} 10:15 WIB 
Lintje Anna Marpaung, Anggalana dan Eky Sepriza, Analisis Implementasi Pembuatan Akta Tanah/Sertipikat Tanah di Badan Pertanahan Nasional Republik Indonesia Melalui Kelompok Masyarakat (POKMAS) Kantor Pertanahan Kabupaten Lampung Barat (Studi di Desa Kuta Besi Kecamatan Batu Brak Kabupaten Lampung Barat)

Barat enggan nya masyarakat setempat untuk melakukan pendaftaran tanah secara sah di kantor Badan Pertanahan Nasional (BPN), sebagian masyarakat mengangap bahwa tanah tersebut milik masyarakat setempat. Karena beralasan tanah tersebut sudah puluhan tahun digunakan oleh masyarakat sekitar dan mengklaim tanah tersebut ialah milik masyarakat setempat tanpa harus di daftarkan kepemilikan hak atas tanah tersebut secara sah, dan juga adanya sebagian masyarakat yang masih buta terhadap hukum tersebut yang menjadikan salah satu masyarakat sekitar tidak mau mengurusnya. Oleh karena itu muncul organisasi yang disebut Kelompok Masyarakat atau yang disingkat (POKMAS) untuk dapat memberikan arahan atau nasihat kepada masyarakat setempat bahwa pentingnya sertipikat kepemilikan atas tanah tersebut sebagai akta autentik dan menghindari adanya kerugian di kemudian hari, fakta yang ada dilapangan belum mengerti tentang pentingnya sertipikat tanah karena banyak masyarakat yang kurang mengerti hukum, Berdasarkan uraian di atas maka diperoleh dua rumusan masalah yaitu: pertama, bagaimana implementasi Pembuatan Sertipikat Tanah di Badan Pertanahan Nasional (BPN) Melalui Kelompok Masyarakat (POKMAS) di Desa Kuta Besi Kecamatan Batu Brak Kabupaten Lampung Barat. Kedua, Faktor-faktor apakah yang menghambat implementasi pembuatan sertipikat tanah di Badan Pertanahan Nasional (BPN) melalui Kelompok Masyarakat (POKMAS) di Desa Kuta Besi Kecamatan Batu Brak Kabupaten Lampung Barat.

\section{METODE}

\section{Metode Pendekatan}

Penelitian ini menggunakan pendekatan yang bersifat yuridis normatif dan empiris

1. Pendekatan yuridis normatif ialah dengan menggunakan perundang-undangan yang terkait dengan Pendaftaran Tanah

2. Pendekatan empiris yaitu dilakukan dengan melihat secara langsug terkait objek penelitian dengan cara observasi dan wawancara

3. Sumber Data terdiri dari bahan

a. Bahan Hukum Primier

1) Undang-Undang Dasar Negara Kesatuan Republik Indonesia Tahun 1945 Hasil Amandemen

2) Undang-Undang Nomor 5 Tahun 1960 tentang Peraturan Dasar Pokok-Pokok Agraria

3) Peraturan Pemerintah Nomor 24 Tahun 1997 Tentang Pendaftaran Tanah

4) Instruksi Presiden Nomor 2 Tahun 2018 Tentang Percepatan Pendaftaran Tanah Sistematis Lengkap

5) Peraturan Menteri Agraria dan Tata Ruang/Kantor Badan Pertanahan Nasional Nomor 6 Tahun 2018 Tentang Pendaftaran Tanah Sistematis Lengkap

6) Surat Keputusan Bersama Menteri Agraria dan Tata Ruang/Kepala Badan Pertanahan Nasional, Menteri Dalam Negeri, Menteri Desa, Pembangunan Tertinggal dan Transmigrasi Nomor 25/SKB/V/2017, Nomor 590-3167A Tahun 2017, Nomor 34 Tahun 2017 Tentang Pembiayaan Persiapan Pendaftaran Tanah Sistematis.

b. bahan hukum sekunder

Bahan hukum sekunder dalam penelitian ini bersumber dari bahan bahan hukum yang dapat membatu menganalisis permasalahan dari berbagai buku hukum, arsip, jurnal dan dokumen.

c. bahan hukum tertier

Bahan hukum teriser dalam penelitian ini bersumber dari Kamus Hukum, Kamus Bahasa Indonesia, Kamus Bahasa Inggris, dan sumber internet.

\section{Prosedur Pengumpulan dan Pengelolan Data}

1. Data Sekunder

Pengumpulan data dengan melakukan serangkaian kegiatan membaca, menelaah, dan menguntip dari bahan kepustakaan serta melakukan pengkajian terhadap ketentuan Peraturan Perundang-udangan yang berkaitan dengan pokok bahasan.

2. Data Primer

a. Pengamatan (Observation) yaitu melakukan pengamatan dan pencataan terhadap data dan fakta yang ada di lokasi penilitian di kantor Badan pertanahan Nasional Lampung Barat dan Pokmas Desa Kuta Besi Kecamatan Batu Brak Kabupaten Lampung Barat

b. Wawancara (Interview), yaitu menggunakan pedoman wawancara yang telah di persiapkan sebelumnya. wawancara dilakukan terhadap narasumber yakni:
1) Ketua BPN Lampung Barat
2) Ketua Pokmas Desa Kuta Besi Lampung Barat
: 1 Orang
: 1 Orang 
Lintje Anna Marpaung, Anggalana dan Eky Sepriza, Analisis Implementasi Pembuatan Akta Tanah/Sertipikat Tanah di Badan Pertanahan Nasional Republik Indonesia Melalui Kelompok Masyarakat (POKMAS) Kantor Pertanahan Kabupaten Lampung Barat (Studi di Desa Kuta Besi Kecamatan Batu Brak Kabupaten Lampung Barat)

\section{Analisis Data}

Analisis data yang digunakan ialah analisis yuridis kualitatif, yaitu dengan memberikan pengertian terhadap data yang diperoleh dilapangan yang kemudian disusun, diuraikan dalam bentuk kalimat

\section{HASIL DAN PEMBAHASAN}

\section{Implementasi Pembuatan Sertipikat Tanah di Badan Pertanahan Nasional (BPN) Melalui Kelompok Masyarakat (POKMAS) di Desa Kuta Besi Kecamatan Batu Brak Kabupaten Lampung Barat.}

Kelompok Masyarakat atau yang disingkat Pokmas merupakan sekelompok masyarakat yang tergerak untuk membantu masyarakat lain dalam melaksanakan Pendaftaran tanah di Desa Kuta Besi Kecamatan Batu Brak Kabupaten Lampung Barat, awal mula berdirinya Pokmas yaitu terdiri dari sekelompok tani yang peduli akan terkait Hak Kepemilikan atas Tanah yang kemudian dibentuklah masyarakat tani tersebut menjadi suatu organisasi yang disebut Pokmas, pendirian Pokmas sendiri berdasarkan Peraturan Menteri Agraria dan Tata Ruang/Badan Pertanahan Nasional Nomor 6 Tahun 2018 tentang Pendaftaran Tanah Sistematis Lengkap. Tujuan utama Pokmas sendiri ialah sebagai upaya untuk membantu masyarakat yang Tanahnya belum didaftarkan Hak Kepemilikannya dapat dibantu oleh kelompok Pokmas tersebut untuk bersedia membantu mendaftarkan Tanah hingga proses penerbitan sertipikat Tanah. Sedangkan dalam Peraturan tersebut bertujuan sebagai upaya mewujudkan kepastian hukum serta perlindungan hukum terkait Hak Kepemilikan atas Tanah masyarakat yang berdasarkan pada asas sederhana, cepat, lancar, aman, adil, merata dan terbuka serta akuntabel, sehingga dapat meningkatkan kesejahteraan dan kemakmuran masyarakat dan ekonomi negara, serta mengurangi dan mencegah sengketa dan konflik pertanahan.

Salah satu terdapatnya Pokmas ialah di Kabupaten Lampung Barat merupakan salah satu Kabupaten yang berada di Provinsi Lampung Indonesia yang tepatnya berada di bawah kaki gunung pesagi dan memiliki nama dengan Ibu Kota Kabupaten Liwa, jika dilihat Kabupaten tersebut didirikan berdasarkan keluarnya Undang-Undang Nomor 6 Tahun 1991 tentang Kabupaten Lampung Barat yang merupakan salah satu Kabupaten dari pemekaran Kabupaten Lampung Utara, Kabupaten Lampung Barat sendiri kebanyakan didominasi dengan perbukitan dengan pantai di sepanjang Kabupaten pesisir barat Lampung, Daerah pegunungan yang merupakan punggung Bukit Barisan, ditempati oleh vulkanik quarter dari beberapa formasi. Daerah ini berada pada ketinggian 50 sampai 1000 mdpl. Daerah ini dilalui oleh sesar Semangka, dengan lebar zona sebesar $20 \mathrm{Km}$. Dengan luas wilayah lebih kurang 3.368,14 $\mathrm{km}^{2}$ Setelah pemekaran Kabupaten Pesisir Barat atau 10,6 \% dari luas wilayah Provinsi Lampung dan mempunyai garis pantai sepanjang $260 \mathrm{~km}$. Lampung Barat terletak pada koordinat 4o,47',16" - 5o,56',42" lintang selatan dan 103o,35',08" - 104o,33',51" Bujur Timur, selain itu Lampung Barat berbatasan dengan Sebelah Utara: Kabupaten Ogan Komering Ulu Selatan (Provinsi Sumatra Selatan), Sebelah Selatan: Kabupaten Pesisir Barat dan Kabupaten Tanggamus, Sebelah Barat: Kabupaten Pesisir Barat, Sebelah Timur: Kabupaten Lampung Utara, Kabupaten Way Kanan, dan Kabupaten Tanggamus. Saat ini Kabupaten Lampung Barat sendiri terdiri dari 15 kecamatan salah satu yang menjadi objek penelitian penulis yaitu di Desa Kuta Besi Kecamatan Batu Brak Kabupaten Lampung Barat terkait implementasi pendaftaran tanah yang dilakukan melalui kelompok masyarakat atau Pokmas.

Pokmas sendiri atau yang disingkat Kelompok Masyarakat merupakan sebuah organisasi yang bertujuan untuk memberikan bantuan atau mensosialisasikan hak kepemilikan tentang Tanah kepada Masyarakat karena masih banyak tanah di Desa Kuta Besi Kecamatan Batu Brak Kabupaten Lampung Barat yang belum didaftarkan atau memiliki sertipikat langsung dari negara oleh masyarakatnya maka dari itu lahirlah organisasi kemasyarakatan yang benaung langsung kepada Badan Pertanahan Nasional Lampung Barat sebagai bentuk implementasi pemberian bantuan kepada masyarakat sekitar bahwa pentingnya pendaftaran tanah untuk melindunggi hak nya dikemudian hari atau sebagai bukti waris terhadap anak-anaknya nanti. ${ }^{7}$

Berdasarkan wawancara penulis dengak Bapak Yusrin sebagai Ketua Pokmas Kelompok Masyarakat di Desa Kuta Besi Kecamatan Batu Brak Kabupaten Lampung Barat Pelaksanaan pendaftaran tanah sendiri melalui Pokmas atau kelompok masyarakat sudah berjalan sejak Tahun 2019 berdirinya Pokmas itu sendiri merupakan salah satu inisiatif masyarakat yang memiliki kesadaran terhadap daerah nya terkait tentang pertanahan yang diketahui masih banyak masyarakat yang enggan atau tidak mengerti bagaimana cara untuk mendaftarakan nya ke Badan Pertanahan Nasional maka hadirlah Pokmas untuk membantu memberikan arahan atau sosialisasi kepada masyarakat sekitar, pokmas sendiri bisa disebut sebagai perpanjangan tangan dari Badan Pertanahan Nasional yang memiliki peranan dan fungsi salah satunya terkaiti menyampaikan informasi langsung ke pada masyarakat yang belum memahami arti penting terhadap sertipikat hak milik dan juga membantu tugas dari Badan Pertanahan Nasional. ${ }^{8}$

\footnotetext{
${ }^{7}$ Yusrin, Ketua Pokmas wawancara dengan penulis, Di Desa Kuta Besi pada Tanggal 1 Februari 2020.

${ }^{8}$ Yusrin, Ketua Pokmas wawancara dengan penulis, Di Desa Kuta Besi pada Tanggal 1 Februari 2020
} 
Lintje Anna Marpaung, Anggalana dan Eky Sepriza, Analisis Implementasi Pembuatan Akta Tanah/Sertipikat Tanah di Badan Pertanahan Nasional Republik Indonesia Melalui Kelompok Masyarakat (POKMAS) Kantor Pertanahan Kabupaten Lampung Barat (Studi di Desa Kuta Besi Kecamatan Batu Brak Kabupaten Lampung Barat)

Jika ada masyarakat yang ingin mendaftarkan tanahnya dapat melalui Pokmas untuk prosesnya yang kemudian oleh Kelompok Masyarakat atau Pokmas akan mengarahkan masyarakat tersebut ke Badan Pertanahan Nasional contohnya ialah masyarakat ke pokmas dari pokmas kemudian ke Badan Pertanahan Nasional. ${ }^{9}$

Setelah diarahkan ke Badan Pertanahan Nasional kemudian masyarakat tersebut akan dilakukan penyuluhan oleh petugas dari Badan Pertanahan Nasional yang menjadi anggota Pokmas Kelompok Masyarakat yang terkait tentang pengumpulan syarat-syarat ataupun berkas-berkas penting permohonan yang harus segera dilengkapi semua persyaratan tersebut kemudian dokumen yang sudah dilengkapi oleh pemohon akan dibawa oleh Pokmas Kelompok Masyarakat yang akan diberikan kepada Badan Pertanahan Nasional yang akan segera diproses di Badan Pertanahan Nasional Lampung Barat. Setelah semua dokumen diperiksa dan dinyatakan lengkap oleh Badan Pertanahan Nasional maka selanjutnya anggota dari Badan Pertanahan Nasional akan diberikan tugas untuk turun langsung dan melakukan pengukuran Tanah yang akan didaftarkan sebagai hak milik dengan diikuti oleh kehadiran dari beberapa anggota Pokmas atau Kelompok Masyarakat untuk membantu atau melihat langsung penggukuran di lapangan.

Kehadiran Pokmas atau Kelompok Masyarakat itu sendiri merupakan salah satu juga yang akan menjadi saksi dilapanggan menjadi saksi terkait dalam proses pelaksanaan pembuatan sertipikat Tanah itu sendiri. ${ }^{10}$

Selain itu adapun keterikatan tentang ketua kampung atau kepala desa sebagai saksi untuk masyarakat maupun Badan Pertanahan Nasional untuk memastikan bahwa Tanah yang sedang didaftarkan dan dilakukan pengukuran tesebut memang benar tanah tersebut milik masyarakat namun belum dilakukan sertipikasi Tanah, jadi peran Kepala Desa dan Pokmas atau Kelompok Masyarakat itu sendiri merupakan bentuk dari perpanjangan tangan dari Badan pertanahan Nasional yang memiliki legal standing yang sudah dikeluarkan oleh Badan Pertanahan Nasional melalui terbitnya surat keputusan atau (SK) yang dikeluarkan oleh Badan Pertanahan Nasional secara langsung.

Sampai akhir Tahun 2020 Tahun lalu Pokmas atau Kelompok Masyarakat dan Badan Pertanahan Nasional diperkirakan sudah menerbitkan sebanyak 4000 sertipikat yang sudah diberikan hak milik kepada masyarakat oleh karena keberhasilan tersebut menjadikan Pokmas dan Badan Pertanahan Nasional diberikan target pada Tahun 2021 dari pusat untuk bisa menerbitkan sebanyak sepuluh ribu sertipikat kepada masyarakat. ${ }^{11}$

Berdasarkan uraian di atas dapat diketahui bahwa implementasi Pendaftaran tanah di Desa Kuta Besi Kecamatan Batu Brak Kabupaten Lampung Barat meskipun sudah berjalan sesuai yang direncanakan untuk membantu masyarakat yang ingin memiliki sertipikat Hak Kepemilikan atas Tanah melalui Kelompok Masyarakat, namun pada pelaksanaannya masih belum maksimal dikarenakan masih terdapat beberapa hambatan yang dirasakan oleh Kelompok Masyarakat dan Badan Pertanahan Nasioanal, hambatan-hambatan tersebut yang menjadikan pelaksanaan pembuatan sertipikat tanah terkadang sedikit memiliki kendala baik itu hambatan secara internal maupun eksternal.

\section{Faktor-faktor penghambat implementasi pembuatan sertipikat tanah di Badan Pertanahan Nasional (BPN) melalui Kelompok Masyarakat (POKMAS) di Desa Kuta Besi Kecamatan Batu Brak Kabupaten Lampung Barat.}

Pembuatan sertipikat tanah merupakan suatu hal yang penting yang harus dilakukan oleh masyarakat yang mempunyai hak milik atas tanah namun pada pelaksanaan pembuatan sertipikat tanah melalui pokmas atau kelompok masyarakat di Desa Kuta Besi Kecamatan Batu Brak Kabupaten Lampung Barat terjadi beberapa faktor penghambat yang di alami oleh BPN melalui pokmas sendiri terjadinya beberapa faktor penghambat tersebut bisa berasal dari faktor internal maupun eksternal faktor internal sendiri adalah dorongan yang muncul pada dirinya sendiri, sedangkan faktor eksternal merupakan faktor yang timbul dari luar dirinya, factor-faktor tersebutlah salah satu penyebab terjadinya hambatan dalam melaksanakan sertipikat tanah yang dilakukan oleh BPN melalui Pokmas atau kelompok masyarakat.

\section{Faktor internal \\ Faktor Pendidikan}

Bahwa faktor pendidikan sebagai salah satu penyebab masyarakat tidak mau nendaftarakan tanahnya dikarenakan masih banyak masyarakat yang belum mengetahui dan mengerti pentingnya mempunyai sertifikat hak milik atas tanah sebagai pembuktian hak milik seseorang atas tanah pengetahuan masyarakat yang kurang terhadap aturan yang ada dalam pertanahan, karena faktor kurangnya pendidikan juga masih banyak masyarakat yang tidak peduli untuk mendaftarkan tanahnya mereka beranggapan bahwa tanah tersebut ialah tanah mereka bukan tanah negara mereka beranggapan tanah tersebut sudah dimiliki oleh mereka dari kakek buyut mereka yang kemudian

\footnotetext{
${ }^{9}$ Yusrin, Ketua Pokmas wawancara dengan penulis, Di Desa Kuta Besi pada Tanggal 1 Februari 2020

${ }^{10}$ Yusrin, Ketua Pokmas wawancara dengan penulis, Di Desa Kuta Besi pada Tanggal 1 Februari 2020

${ }^{11}$ Yusrin, Ketua Pokmas wawancara dengan penulis, Di Desa Kuta Besi pada Tanggal 1 Februari 2020
} 
Lintje Anna Marpaung, Anggalana dan Eky Sepriza, Analisis Implementasi Pembuatan Akta Tanah/Sertipikat Tanah di Badan Pertanahan Nasional Republik Indonesia Melalui Kelompok Masyarakat (POKMAS) Kantor Pertanahan Kabupaten Lampung Barat (Studi di Desa Kuta Besi Kecamatan Batu Brak Kabupaten Lampung Barat)

diturunkan kepada anak-cucu nya dan tidak perlu lagi untuk didaftarkan, ini lah pentingnya pendidikan terhadap masyarakat sebagai usaha untuk bisa mencerdaskan masyarakat salah satunya pada bidang pertanahan. ${ }^{12}$

\section{Faktor individu}

Faktor individu sendiri ialah dimaksud dengan rasa keingginan yang timbul dari diri masyarakat yang rendah ada sebagian dari masyarakat yang memang belum menggurus terhadap hak kepeimilikan Tanah di Badan Pertanahan Nasional melalui Kelompok Masyarakat biasanya masyarakat yang malas menggurus sertipikat Hak Milik dikerenakan kurangnya pengetahuan atau informasi, mereka enggan untuk mencari informasi tentang hak milik atas pertanahan, sebagian dari masyarakat tersebut masih menganggap Tanah yang sudah mereka kelola dari kakek mereka tidak perlu didaftarkan kembali karena dengan sendirinya Tanah tersebut sudah jatuh ke tangan mereka tanpa didaftarkan ke Badan Pertanahan Nasional, padahal dalam undang-undang menggatakan untuk menjamin kepastian hukum oleh Pemerintah dengan menerbitkan sertipikat hak atas tanah sebagai bukti kepemilikan seseorang atas suatu Tanah aupun bangunan.

\section{Faktor Biaya}

Faktor Biaya pengurusan merupakan salah satu penghambat yang dialami oleh Pokmas dan Badan Pertanahan Nasional, oleh karena masih banyak masyarakat yang tidak mau mengurus dengan alasan tidak memiliki biaya pengurusan, padahal sertipikat hak milik sangatlah penting untuk membuktikan bahwa memang benar dialah yang memiliki Tanah tersebut. Pengurusan biaya sendiri mecapai enam ratus ribu untuk satu sertipikat yang sudah diterima jadi, padahal sesungguh nya biaya pengurusan Tanah lebih mahal bila diurus oleh institusi lain seperti notaris, ${ }^{13}$

\section{Faktor Eksternal}

\section{Faktor tanah yang masuk kawasan hutan lindung atau TNBBS (Taman Nasional Bukit Barisan Selatan)}

Faktor penghambat lain ialah adanya sebagian masuknya tanah masyarakat ketika dilakukan penggukuran oleh Pokmas atau Kelompok Masyarakat ternyata Tanah tersebut masuk kedalam kawasan hutan lindung, banyak tanah yang ketika sudah dilakukan pengukuran oleh Kelompok Masyarakat dilapanggan ternyata ada sebagian bidang Tanah dari masyarakat sebagai kawasan atau tanah lindung ini juga salah satu hambatan yang dirasakan oleh pokmas karena masyarakat tersebut tidak dapat mendaftarkan tanahnya ke Badan Pertanahan Nasional untuk menjadi hak miliknya karena Hutan lindung merupakan sebagai wilayah kawasan hutan yang memiliki fungsi untuk perlindungan terhadap sistem penyangga kehidupan yang mengatur tata air, mencegah banjir, dan memelihara kesuburan tanah oleh karena hal tersebutlah kawasan hutan lindung tidak dapat didaftarkan oleh pokmas. ${ }^{14}$

\section{Kurangnya Kesadaran Masyarakat Dalam Melengkapi Dokumen Yang Diperlukan}

Penghambat lainnya ialah masih didapati adanya masyarakat yang kurang mengerti sehingga ketika melakukan pendaftaran sertipikat hak milik masih terdapat beberapa masyarakat kurangnya melengkapi dokumen persyaratan pendaftaran tanah di Kelompok Masyarakat atau Pokmas sehingga ini menjadi penghambat yang lain karena akan memakan waktu untuk menunggu kembali masyarakat untuk melengkapi prosedur persyaratan terkait dokumen kepemilikan. ${ }^{15}$

Berdasarkan hal di atas menurut penulis bahwa pelaksanaan pendaftaran tanah melalui kelompok masyarakat atau Pokmas Di Desa Kuta Besi Kecamatan Batu Brak Kabupaten Lampung Barat sudah berjalan dengan baik dalam pelaksanaan di lapangan meskipun terjadi beberapa hambatan seperti halnya kurangnya persyaratan dokumen yang harus dilengkapi masyarakat atau ketika dilakukan pengukuran terhadap tanah yang didaftarkan tanah tersebut masuk kedalam tanah kawasan atau hutan lindung, dalam hal seperti ini kelompok masyarakat atau Pokmas dan Badan Pertanahan Nasional tidak dapat menolong masyarakat yang Tanah nya termasuk Tanah kawasan Hutan Lindung namun jika tidak maka Pokmas dan Badan Pertanahan Nasioanl akan membantu para masyarakat yang mendaftarkan Tanahnya sampai dengan penerbitan sertipikat hak kepemilikan atas tanah yang diterbitkan hanya satu kali dalam satu setahun, diantara beberapa hambatan yang paling sering terjadi pada pelaksanaan pendaftaran tanah ialah masuknya Tanah masyarakat kedalam kawasan Hutan Lindung dalam kasus seperti ini baik Kelompok Masyarakat ataupun Badan Pertanahan Nasional tidak dapat berbuat banyak selain harus memberhentikan pengukuran dilapangan masyarakat yang terdampak harus melepaskan tanah tersebut, karena tanah tersebut tidak dapat diterbitkan sertipikat

\footnotetext{
${ }^{12}$ Sahrial, pegawai BPN Lampung, wawancara dengan penulis, di BPN pada Tanggal 3 Februari 2021

${ }^{13}$ Sahrial, pegawai BPN Lampung, wawancara dengan penulis, di BPN pada Tanggal 3 Februari 2021

${ }^{14}$ Sahrial, pegawai BPN Lampung, wawancara dengan penulis, di BPN pada Tanggal 3 Februari 2021

${ }^{15}$ Sahrial, pegawai BPN Lampung, wawancara dengan penulis, di BPN pada Tanggal 3 Februari 2021
} 
Lintje Anna Marpaung, Anggalana dan Eky Sepriza, Analisis Implementasi Pembuatan Akta Tanah/Sertipikat Tanah di Badan Pertanahan Nasional Republik Indonesia Melalui Kelompok Masyarakat (POKMAS) Kantor Pertanahan Kabupaten Lampung Barat (Studi di Desa Kuta Besi Kecamatan Batu Brak Kabupaten Lampung Barat)

oleh Badan Pertanahan Nasional karena kawasan hutan lindung sendiri sebagai kawasan yang tidak boleh dimiliki oleh siapapun karena kegunaan sendiri dimiliki oleh seluruh masyarakat.

\section{SIMPULAN}

1. Implementasi Pembuatan Sertipikat Tanah masyarakat dapat meminta bantuan kepada Pokmas dengan cara membawa seluruh persyaratan yang dibutuhkan, kemudian Pokmas akan membawa persyaratan tersebut ke BPN dan kemudian anggota BPN akan memeriksa kelengkapan persyaratan tersebut, jika lengkap maka ketua BPN akan menyuruh anggota nya dibantu POKMAS untuk segera mengukur dan menerbitkan sertipikat hak atas tanah,

2. Faktor penghambat terdiri dari faktor internal dan eksternal yaitu, faktor internal terdiri dari, Faktor Pendidikan yang paling utama yang mempengaruhi masyarakat sendiri, tidak mengertinya masyarakat akan pentingnya hak milik atas tanah menjadi faktor penghambat, Faktor individu sendiri merupakan masih didapati masyarakat yang malas untuk mendaftarkan anah mereka meskipun mereka mengetahui pentingnya hak milik atas tanah namun mereka enggan untuk segera mendaftarkan tanah tersebut. Faktor Biaya menjadi salah satu faktor penghambat berikutnya kerena masih terdapat masyarakat yang tidak mampu membayar terhadap proses pendaftaran tanah tersebut.

\section{DAFTAR PUSTAKA}

\section{Buku}

Arie Sukanti Hutagalung. 2012. Pentingnya Pendaftaran Tanah di Indonesia. Raih Asa Sukses, Jakarta. Arba. 2017. Hukum Agrarian Indonesia. Sinar Grafika, Jakarta.

A. P. Parlindungan. 1993. Komentar Undang-Undang Pokok Agraria. Mandar Maju, Bandung.

\section{Jurnal}

Steven Octovia Kennedy Wowor. 2016. Responsivitas Dalam Pendaftaran Peralihan Hak Atas, Tanah Jual Beli Di Kantor Pertanahan Dikabupaten Sigi Provinsi Sulawesi Tengah. E Jurnal Katalogis, Volume 4 Nomor 1.

\section{Internet}

Kamus Besar Bahasa Indonesia, Diakses 22 Oktober 2020

https://www.seputarpengetahuan.co.id.Pengertian-Tanah-Menurut-Para-Ahli.html. Diakses Pada Tanggal 22/10/2020 Jam 10:15 WIB

\section{Wawancara}

Sahrial, pegawai Badan Pertanahan Nasional Lampung, wawancara dengan penulis, di BPN pada Tanggal 3 Februari 2021

Yusrin, Ketua Kelompok Masyarakat (Pokmas) wawancara dengan penulis, Di Desa Kuta Besi pada Tanggal 1 Februari 2020 